\title{
The Inner Wall of The Tank Painted in Black is Good for Larval Rearing of Yellowfin Tuna Thunnus albacares
}

\author{
Jhon Harianto Hutapea, Gunawan, Ananto Setiadi and Bedjo Slamet \\ Institute for Mariculture Research and Fisheries Extension \\ Email: hutapeaharianto@gmail.com
}

Received: 7 October 2019; Accepted: 28 November 2019

\begin{abstract}
Jhon Harianto Hutapea, Gunawan, Ananto Setiadi and Bedjo Slamet. 2019. The inner wall of the tank painted in black is good for larval rearing of Yellowfin tuna Thunnus albacares. Aquacultura Indonesiana, 20(2) : 102-108- . Institute for Mariculture Research and Fisheries Extension have been able to spawn yellowfin tuna in the floating nets cage (FNC) since 2015. However, the number of juveniles produced is still low due to the high mortality of larvae at the first ten days of rearing and when metamorphoses into juveniles. The inner wall color of tank is suspected to affect the survival of early larvae stage. The purpose of the study is to get suitable inner wall color of the tank to increase growth and survival rate. Eggs were harvested from FNC and stocked 20 eggs/L in 5 pieces of Fiberglass Reinforced Plastic tanks, volume of $6 \mathrm{~m}^{3}$ each. Treatments were: A. Gray, B. Blue, C. Yellow, D. Black, and E. White, 3 replication. Hatching rate of eggs at treatment (A) was $60.39 \%$, blue (B) $76.64 \%$, yellow (C) $61.74 \%$, black (D) $71.08 \%$ and white (E) $69.19 \%$. Daily observation of Yellowfin tuna larvae kept in blue, yellow and white inner wall tanks patched in the corner near the surface of the tank. While the larvae in the gray and black inner wall tanks distributed evenly either in the surface layer and water column. The survival rate of juvenile in black inner wall tank is better than other color treatments, although statistically does not significantly different.
\end{abstract}

Keywords: Larvae, survival rate, yellowfin tuna, tank, inner wall color.

\section{Introduction}

Success of Institute for Mariculture Re search and Fisheries Extension (IMRAFE) in develop technology on culture and breeding of yellowfin tuna nearly completes. This achievement is based on a series of experiment such as captured and transported alive tuna, growth, gonad maturation and spawning both in concrete tank and in floating net cage. Due to the discontinuity of research, the larval rearing is still left behind. The limiting factor in seed production and nursery is still need to be solved intensively.

The research on the yellowfin tuna in IMRAFE has actually begun since 2003. Cultivation, maturation and spawning in a concrete tank has been successful since 2004 . In 2006 has managed to produce one hundred seed at total length of $3-5 \mathrm{~cm}$. Several scientific papers were published such as captured and transportation of candidate broodstock (Hutapea, et al. 2010), broodstock rearing (Hutapea and Permana, 2006), Broodstock DNA mapping (Permana et al. 2007), spawning, eggs and larvae handling
(Zafran et al. 2006; Hutapea, 2007; Hutapea et al. 2007).

During 2008 to 2010 , effort to revitalize the existing broodstock and collecting some broodstock candidates was done under collaboratian research with Australian Centre for International Agricultural Research (ACIAR) (Hutchinson, et al. 2010).

In 2013, the tuna research activities are re-implemented by the installation of a floating net cage (FNC). In the same year there were captured, transported and rearing of the yellowfin tuna candidate broodstock in the FNC (Hutapea, et al. 2014) and in 2015 some fishes maturated and spawned (Hutapea, et al. 2015). Based on larval rearing trials throughout the year of 2015, there were three periods of larval mortality, i.e. early stage, after 10 days old and approaching metamorphose to Juvenile (Hutapea, et al. 2015) and the same phenomenon is also found in other countries that doing tuna breeding (Kjorsvik et al., 2004; Nakagawa, et al. 2011). Mortality in this early stage is related to specific factors such as the low ability of 
larvae to capture prey and the availability of feed (Reglero et al. 2014). Other factors importance in larval rearing may be tank size, tank color, turbidity, food quality, and prey densities (van der Meerena, et al. 2007).

Mortality in larval rearing of tuna could be divided into three phase. Firstly, high mortality in the first ten days after hatch $(10$ DAH) is related to eggs quality, feed nutrition and environmental condition such as light intensity, dissolved oxygen, ammonia, nitrite and osmosis pressure in water media (Kaji, 1998). Feed size also affects on growth rate of larvae (Miyashita et al. 2001). The second high mortality happens in around $20 \mathrm{DAH}$, where larvae tend to chase and prey the other larvae (cannibalism) (Reglero et al. 2014). The third high mortality happens when the larvae metamorphoses to juvenile with its swimming ability nearly to completely develop, its behavior to chase other juvenile, hit the tank wall or jump out the tank and cause the increase of mortality (Kaji,1998).
The purpose of the study is to know the appropriate inner wall color of the tank that suitable for the larval rearing of yellowfin tuna to promote growth and survival rate of the juvenile.

\section{Material and Method}

This trial was conducted in the hatchery of IMRAFE. Viable yellowfin tuna eggs were collected from natural spawning in FNC, then introduced into five pcs of Fibreglass Reinforced Plastic (FRP) tanks, with volume of $6 \mathrm{~m}^{3}$ each, and the density was $20 \mathrm{eggs} / \mathrm{L}$. Each inner wall and bottom tank was painted with different color and use as treatment: A. Brown, B. Blue, C. Yellow, D. Black, and E. White, with three replication. At the first day sampling was conducted in order to obtain the hatching rate at each tank then larval rearing was continued following the feeding regime and water management as shown in Table 1 and 2 .

Table 1. Feeding regime of yellowfin tuna larva rearing

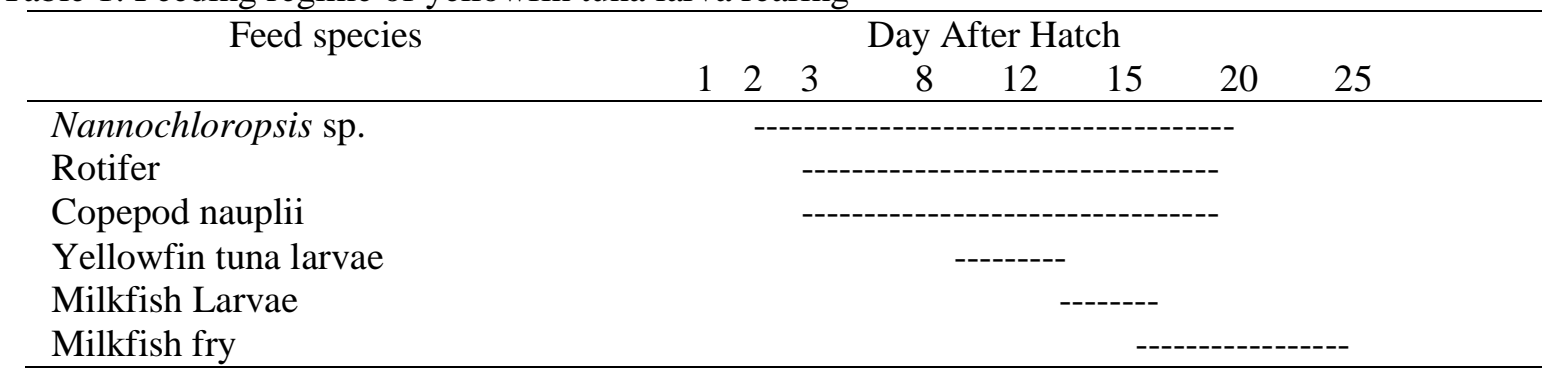

Table 2. Fish oil dispersion on water surface, Water management, and bottom cleaning during yellowfin tuna larval rearing

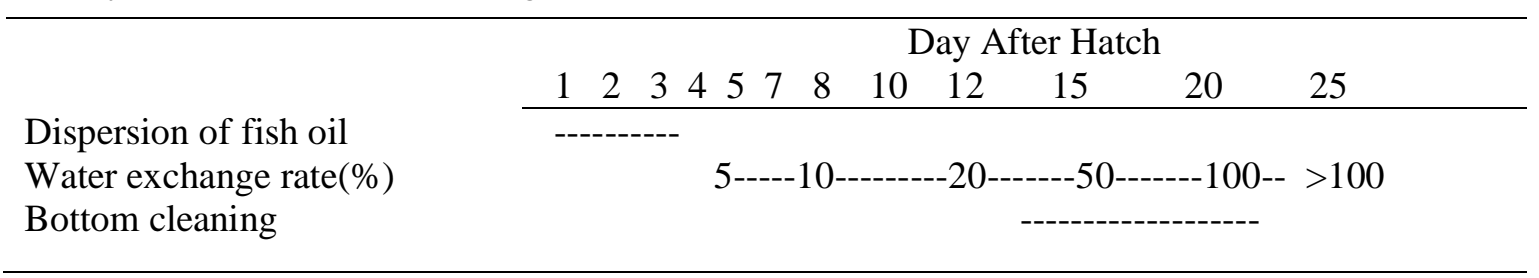

Daily observations such as larval behaviour, sampling number of the remaining rotifera in the larval tank, counting the number of eaten rotifers, measurements and observations of the development of larvae morphology and periodic sampling for histological preparations. The water quality parameters measured were dissolved oxygen, salinity, temperature and $\mathrm{pH}$ and a regular bacterial monitoring using Triptic Soy Agar (TSA) method.
Ten pieces of larvae were taken daily from D-1 to D-10, and every three days from D-13 to D-20 to measure the growth and morphological development of larvae. For measurement, the larvae were observed under a microscope that was connected to the camera and computer application Image capture ACT1 and measurement application WinRoof. After measurement and observation, samples were pressed with a glass cover and count the rotifer and other feeds in the stomach of larvae 


\section{Results and Discussion}

The results showed that hatching rate of eggs on each treatment of different inner wall tank color was, gray color $60.39 \%$, blue $76.64 \%$, yellow $61.74 \%$, black $71.08 \%$ and white inner wall tank color was $69.19 \%$ and there is no significantly different among the treatments $(\mathrm{P}>0.05)$, as shown in Table 3 .

Table 3. Results of larval rearing of yellowfin tuna using different inner wall color

\begin{tabular}{|c|c|c|c|c|c|}
\hline \multirow{2}{*}{ Items } & \multicolumn{5}{|c|}{ Treatment- Inner wall color } \\
\hline & Gray & Blue & Yellow & Black & White \\
\hline $\begin{array}{l}\text { Total number } \\
\text { of eggs (pcs) }\end{array}$ & 100,000 & 100,000 & 100,000 & 100,000 & 100,000 \\
\hline $\operatorname{HR}(\%)$ & $60.39 \pm 25.09^{\mathrm{a}}$ & $76.64 \pm 16.88^{\mathrm{a}}$ & $61.74 \pm 20.47^{\mathrm{a}}$ & $71.08 \pm 17.05^{\mathrm{a}}$ & $69.19 \pm 19.49^{\mathrm{a}}$ \\
\hline $\begin{array}{c}\text { Total length } \\
\text { of newly } \\
\text { hatch larvae } \\
(\mathrm{mm})\end{array}$ & $2.71 \pm 0.70^{\mathrm{a}}$ & $2.71 \pm 0.70^{\mathrm{a}}$ & $2.71 \pm 0.70^{\mathrm{a}}$ & $2.71 \pm 0.70^{\mathrm{a}}$ & $2.71 \pm 0.70^{\mathrm{a}}$ \\
\hline $\begin{array}{c}\text { Total length } \\
\text { of juvenile } \\
\text { harvested } \\
(\mathrm{mm})\end{array}$ & $33.32 \pm 2.66^{\mathrm{a}}$ & $31.06 \pm 1.99^{a}$ & $31.21 \pm 2.31^{\mathrm{a}}$ & $28.20 \pm 1.87^{\mathrm{a}}$ & $32.54 \pm 2.21^{\mathrm{a}}$ \\
\hline $\begin{array}{c}\text { Total number } \\
\text { of juvenile } \\
\text { harvested } \\
\text { (pcs) }\end{array}$ & $313 \pm 254^{\mathrm{a}}$ & $288 \pm 279^{a}$ & $171 \pm 148^{a}$ & $426 \pm 353^{\mathrm{a}}$ & $217 \pm 233^{a}$ \\
\hline $\begin{array}{c}\text { Water } \\
\text { temperature } \\
\text { range }\left({ }^{\circ} \mathrm{C}\right)\end{array}$ & $27.00-30.50$ & $27.00-30.80$ & $27.00-30.00$ & $27.00-30.80$ & $27.00-30.50$ \\
\hline $\begin{array}{c}\text { Light } \\
\text { intensity } \\
\text { range (Lux) }\end{array}$ & $615-2,160$ & $642-2,920$ & $655-3,690$ & $541-2,220$ & $955-5,290$ \\
\hline $\mathrm{pH}$ & $7.99-8.12$ & $8.00-8.15$ & $8.00-8.17$ & $8.01-8.12$ & $8.00-8.15$ \\
\hline $\mathrm{DO}(\mathrm{mg} / \mathrm{L})$ & $6.80-7.60$ & $6.75-7.50$ & $6.90-7.60$ & $6.80-7.60$ & $6.90-7.60$ \\
\hline Salinity (ppt) & $33-34$ & $33-34$ & $33-34$ & $33-34$ & $33-34$ \\
\hline $\begin{array}{l}\text { Ammonia } \\
(\mathrm{mg} / \mathrm{L})\end{array}$ & $0.23-0.89$ & $0.14-0.69$ & $0.21-0.75$ & $0.24-0.82$ & $0.12-0.67$ \\
\hline $\begin{array}{l}\text { Nitrite } \\
(\mathrm{mg} / \mathrm{L})\end{array}$ & $0.08-0.21$ & $0.05-0.21$ & $0.05-0.21$ & $0.14-0.21$ & $0.03-0.17$ \\
\hline $\begin{array}{l}\text { Phosphate } \\
\text { (mg/L) }\end{array}$ & $0.07-0.30$ & $0.07-0.29$ & $0.09-0.28$ & $0.09-0.33$ & $0.03-0.25$ \\
\hline $\begin{array}{l}\text { Total bacteria } \\
\text { (CFUx10 } \\
3 / \mathrm{mL})\end{array}$ & $0.89-9.70$ & $0.87-28.00$ & $1.60-12.00$ & $2.00-14.00$ & $0.94-10.00$ \\
\hline
\end{tabular}

Note: Hatching rate based on sampling at $1 \mathrm{DAH}$

Harvest/Count the survival juvenile was at $25 \mathrm{DAH}$

Number followed by the same letter is not significantly different

It is known that since 3 day after hatch (DAH), the yellowfin tuna larvae had been actively swimming to search for feed. The introduction of rotifer and copepod nauplii as the initial feed for yellowfin tuna larvae was proved effective. Based on the observation, the stomach of the larvae starting from D-3 has already contained rotifers and nauplii copepods on all treatments. The number of rotifers and nauplii copepods in the stomach of the most samples of yellowfin tuna larvae increases in accordance with the age increase, but in some samples also found the stomach content decrease (Figure. 1). 


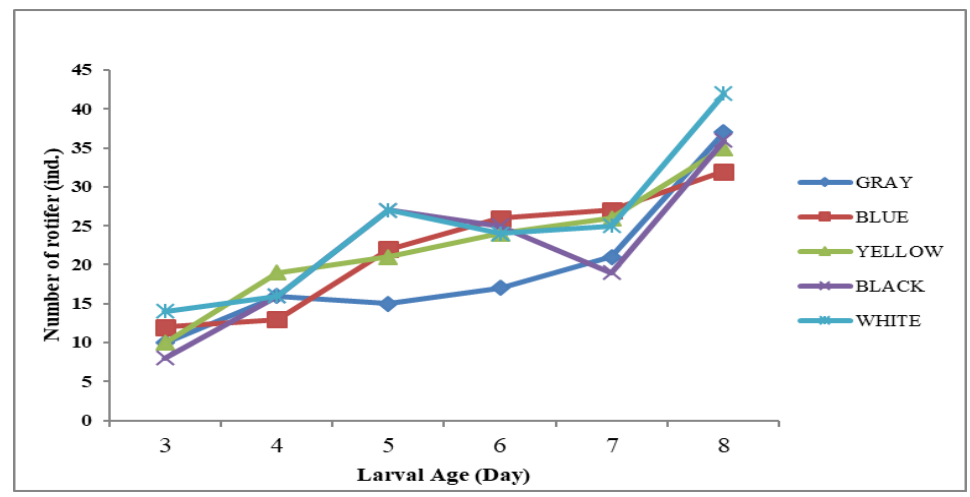

Figure 1. The number of rotifers and nauplii copepods in the stomach of the yellowfin tuna larvae

Stomach content after 8 DAH was not presented because the number were to high and the species were not been able to identified related to the addition not only rotifer and nauplii of copepods but also addition of Artemia instar and newly hatch larvae of tuna.

Based on daily observation, larval swimming behavior up to $13 \mathrm{DAH}$, gray, yellow, and white inner wall tanks tended to gather in the corners of the tank near the surface layer. While the larvae reared in a blue and especially those in a black tank, larvae spread evenly in the water surface layer and spread into the water column. In contrary, milkfish (Chanos chanos) larval visibility enhancement in solar illuminated yellow tank act synergistically to perform necessary foraging to acquire nutritional energy for metamorphosis to fry (Bera et al, 2019). While Takeshita and Soyano (2008) reported that color of the rearing tank affect the occurrence on cannibalism in the juvenile orange-spotted grouper and found that in the red tank group, mortality was significantly lower than that in the green tank. According to (Ina et al. (2017), Pacific blue fin tuna Thunnus orientalis larvae, after 3 DAH $(3.7 \pm 0.1 \mathrm{~mm}$ BL) start develop photo taxis positive when the eyes of the larvae were pigmented and most fish moved into the $7.0 \times 10^{4}$ lux section in the illumination gradient tank. Some possible causes of a decrease in the amount of feed in the stomach content of the larva and juvenile is the transition type and size of feed, increase the digestive rate or due to deterioration of environmental conditions that that cause larvae stress. It is estimated that the decrease of stomach contents of larvae at seven days old coincided with the feeding transition from the plankton feeder into the piscivorous mode. The larvae of yellowfin tuna that enters the piscivorous mode seeks to get the smaller fish larvae as feed, so at this period, it is necessary to provide enough number of newly hatch larvae in the rearing tank.

Total length measurements at the end of the study, the yellowfin tuna juvenile from the grey tank provide better growth compared to other treatments. But statistical analysis of the five treatments, the growth rate was not significant different $(\mathrm{P}>0.05)$ as seen in Table 3 . The daily total length growth rate of the yellowfin tuna larvae in this study was presented in Figure 2.

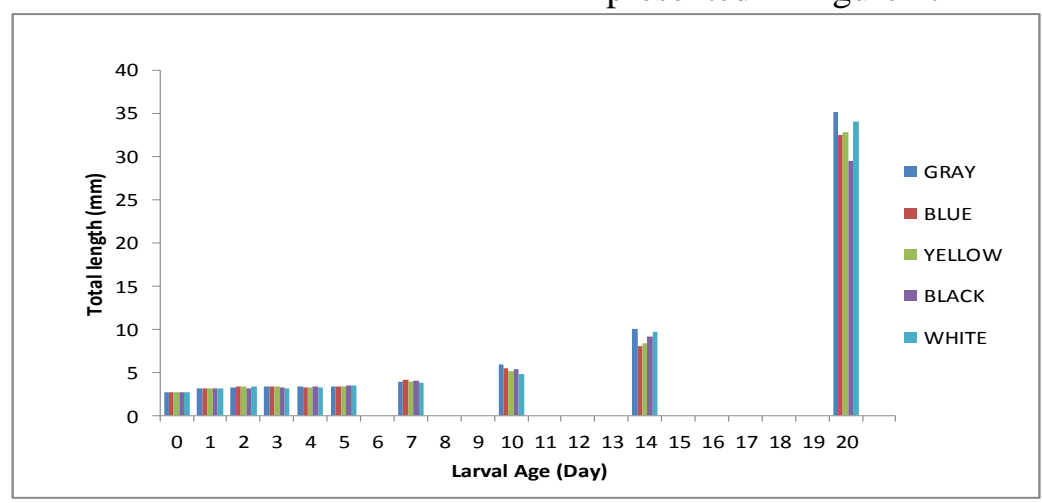

Figure 2. Daily growth of yellowfin tuna larvae total length 
In order to reduce cannibalism, tuna juvenile from hatchery must be harvested, selected by size and moved into the nursery tanks. The number of juvenile produced from each treatment was seen in Table 4. The survival rate of juvenile from the black tank is better compared to other color treatments, but the statistical analysis does not show a significant different from the five treatments
$(\mathrm{P}>0.05)$, as seen in the Table 3. This occurs because there was a very large difference between repetitions (Table 4). This difference leads to a high standard of deviation which further affected on statistical analysis. The low final result of this study occurs because cannibalism was so high, especially in black inner wall color of tank.

Table 4. Number of yellowfin tuna juvenile produced in research conducted using different inner wall color of the tank

\begin{tabular}{cccccc}
\hline Replication & \multicolumn{5}{c}{ Treatments } \\
\cline { 2 - 6 } & Gray & Blue & Yellow & Black & White \\
\hline I & 31 & 4 & 3 & 35 & 8 \\
II & 525 & 299 & 228 & 721 & 174 \\
III & 384 & 562 & 283 & 524 & 217 \\
\hline
\end{tabular}

Cannibalism in tuna juvenile is different from that of grouper fish. In tuna, predators are attracted to the color of the prey, when it was captured but cannot be swallowed because the width of the juvenile body does not fit to its mouth width. Then released it and again look for the other prey. While in grouper fish, generally cannibalism occurs because it needs as feed and once it can prey on other juvenile, cannibalism will cease for a while. If it is not able to swallow the prey, both juvenile will dead. While in tuna juvenile, the death of prey increased is not because it is eaten but because it is bitten but cannot be swallowed. The level of cannibalism in tuna fish is much higher than the grouper as it will continue to attack other smaller tuna juvenile.

Measurement of light intensity is done morning and afternoon, on the surface layer, mid-water column and near the bottom of each tank. It is very clear that the light intensity in the white is much higher than in the others tanks, especially in the gray and black inner wall tank color. The nature of light penetrating into the water media in a black inner wall color was not reflected, on the contrary the light penetrating into the white inner wall was reflected more compare to other inner wall color. One direction of light makes larvae easier to see and determine feed position. Conversely in a white inner wall where light is scattered and causing larvae have difficulty on seeing and determining feed position. It can be seen that until $10 \mathrm{DAH}$ or before the larvae turn into piscivorous, the survival rate of larvae in black tank is still very high, whereas in white tank is very low. But this is also becomes an obstacle in black inner wall tank, when the larvae metamorphose into juveniles, high cannibalism characteristics cause many juveniles die due to predation. So the survival rate at the end of the study became low and not significantly different compared to other treatments.

In order to understand the effect of different inner wall tank color to the ability of larvae to adjust its eyes, histology preparations are displayed in figure 3 as shown below.
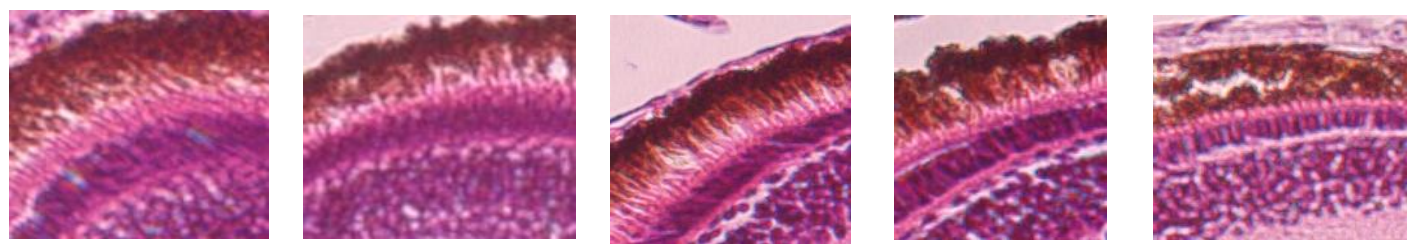

Figure 3. Preparat histological section, Haematoxylin and Eosin staining of five day after hatch (5 DAH) yellowfin tuna larvae reared at different inner wall color

(from left to the right: White, Black, Yellow, Blue and Gray color; Magnification $400 \mathrm{X}$ )

It is clearly shown the distance from retinal pigment epithelium to the outer limiting membrane of larvae eye reared in white inner wall tank was wider compare to larvae eye reared in black inner wall tank. 


\section{Conclusions}

The yellowfin tuna larvae is able to well utilize rotifers and copepod nauplii as the initial feed at all the treatments of different inner wall color.

The distribution of yellowfin tuna larvae from $3 \mathrm{DAH}$ to nearly the metamorphous to juvenile, in the tank with blue inner wall color and especially in the black inner wall tank spreads evenly both horizontally and vertically.

The distribution of yellowfin tuna larvae from 3 DAH to nearly the metamorphous to juvenile, in the tank with white, gray, yellow, and gray inner wall color of the tank is likely to be patched around the corner of the tank near the surface water layer.

The best color for yellowfin tuna larval rearing is a tank with black inner wall color, but a modification is still needed to prevent a tendency the increase of cannibalism starting from $15 \mathrm{DAH}$.

\section{References}

Annonimous. 2015.. Southern Bluefin Tuna. Down loaded on Juni 16, 2015. http://en. wikipedia.org

Annonimous 2007.. Spawning and early develop ment of ca ptive yellowfin tuna (Thunnus albac ares) in Panama. Down loaded on November 25, 2015. http : // The free Library

Bera, A., Kailasam, M., Mandal, B., Sukumaran, K., Makesh,M., Hussain,T., Sivarama krishnan, T., Subburaj, R., Thiagarajan, G. and Vijayan, K.K. 2019. Effect of tank colour on foraging capacity, growth and survival of milkfish (Chanos chanos) larvae. Aquaculture, Volume 512, 2019, pp. 207-216

Hutapea, J.H. \& Permana G.N. 2006. In Anoni mous 2006. Final Joint Committee Meeting of the Project for the Research on Propagation of Tuna Species in the Republic Of Indonesia. 100 pp.

Hutapea, J.H. 2007. Pengamatan perkembangan embrio Tuna sirip kuning (Thunnus albacares) dalam suhu inkubasi yang berbeda. Prosiding Seminar Nasional Perikanan dan Kelautan. Semarang. pp 123-128.

Hutapea, J.H., Permana, I G.N. \& Andamari, R. 2007. Perkembangan embrio ikan tuna sirip kuning (Thunnus albacares). J.Ris. Akuakultur. Vol.2 No.1. pp 9-14.
Hutapea, J.H., Permana, I G.N. \& Andamari, R. 2007. Pengaruh salinitas terhadap sintasan larva stadia awal ikan tuna sirip kuning (Thunnus albacares). Pengembangan Teknologi Budidaya Perikanan. pp 127-131.

Hutapea, J.H. 2007. Pengamatan perkembangan embrio Tuna sirip kuning (Thunnus albacares) dalam suhu inkubasi yang berbeda. Prosiding Seminar Nasional Perikanan dan Kelautan. Semarang. Hal. 123-128.

Hutapea, J.H., G.N. Permana dan R. Andamari. 2007. Perkembangan embrio ikan tuna sirip kuning (Thunnus albacares). J.Ris. Akuakultur. Vol.2 No.1. Hal.9-14.

Hutapea, J.H., Setiadi, A., Gunawan and Permana, G.N. 2010. Perbaikan teknik penanganan calon induk ikan tuna siripkuning (Thunnus albacares) pasca penangkapan dan dalam bak pengobatan. Forum Inovasi Teknologi Akuakultur 2010. Buku 1. p: 359-365

Hutapea, J.H., Setiadi, A., Gunawan \& Permana, I G. N. 2014, Evaluasi produktivitas Induk Ikan Tuna Sirip Kuning (Thunnus albacares) dalam KJA dan perbaikan teknik pemeliharaan larva. $15 \mathrm{pp}$.

Hutapea, J.H., Setiadi, A., Gunawan \& Permana, I G. N. 2015. Kajian teknologi budidaya ikan tuna sirip kuning, Thunnus albacares di bak dan KJA. Laporan Teknis. 13 pp.

Hutchinson, W., Partridge, G. and J.H. Hutapea. 2011. Achieving consistent spawning of captive yellowfin tuna (Thunnus albaca res) broodstock at Gondol Resear ch Institute for Mariculture, Bali, Indonesia. $33 \mathrm{pp}$

Ina, Y., Sakakura, Y., Tanaka, Y., Yamada, T., Kumon, K., Eba, T., Hashimoto, H.Konishi, J., Takashi T., Gen, K. 2017. Development of phototaxis in the early life stages of Pacific bluefin tuna Thunnus orientalis. Fisheries Science. Vol83. Issue 4: 537-542

Kaji, T. 1998. Bluefin Tuna larval rearing and development. State of the art. pp 84-89.

Kjorsvik, E., Pittman, K., \& Pavlov, D. 2004. From fertilisation to the end of metamorpho sis-functional development. In: Moksne ss, E., Kjorsvik, E., Olsen, Y. (Eds.), Culture of Cold-Water Marine Fish. Blackwell Publishing, Carlton, Victoria, pp. 204-278.

Meerena, van der. T., Jensena, A. M., Pickova, J. 2007. The effect of green water and light intensity on survival, growth and lipid composition in Atlantic cod (Gadus morhua) during intensive larval rearing. 
Aquaculture, Volume 265, Issues 1-4, 1 May 2007, pp 206-217.

Miyashita, S., Sawada, Y., Okada, T., Murata, O., \& Kumai, H. (2001). Morphological development and growth of laboratoryreared larval and juvenile Thunnus thynnus (Pisces: Scombridae). Fish. Bull., 99: 601-616.

Nakagawa, Y., Kurata, Makamoto, W., \& S. Miyashita. 2011. Enhancement of survival rate of Pacific bluefin tuna (Thunnus orientalis) larvae by aeration control in rearing tank. Aquat.Lining Resour.24, pp 403-410.

Permana, G.N., J.H. Hutapea, Haryanti dan S.B.M. Sembiring. 2007. Variasi genetik ikan tuna sirip kuning, Thunnus albacares dengan analisis elektroforesis allozyme dan Mt-DNA. J.Ris. Akuakultur. Vol.2 No.1. Hal. 41-50.

Reglero, P., Blanco, E., Ortega, A., Fiksen, Ø., de la Gándara, F., Seoka, M., Viguri, F.J. and A. Folkvord. 2015. Prey selectivity in piscivorous bluefin tuna larvae reared in the laboratory. Journal of Plankton Research, Volume 37, Issue 1, January/February 2015, pp 2-5

Setiadi, A., Hutapea, J.H. \& Gunawan. 2015. Hatching rate of Yellowfin tuna Thunnus albacares under various aeration rate. Unpublish.

Takeshita, A., and Soyano, K. 2008. Effects of Light Intensity and Color of Rearing Tank on Cannibalism in the Juvenile Orange-Spotted Grouper (Epinephelus coioides). Aquaculture Sci.56 (2), pp $175-180$.

Zafran, J.H. Hutapea, D. Rosa dan F. Johny. 2006. Infeksi endoparasit protista ada telur ikan tuna sirip kuning (Thunnus albacares). Prosiding Konferensi Akuakultur Indonesia 2006. p:77-80. 